\title{
Üçüncü Basamak Sağlık Merkezinde Genç İskemik İnme Hastalarında Etiyolojik İnceleme
}

\author{
Etiological Investigation of Young Ischemic Stroke Patients in the Tertiary Health Centre \\ Rahşan Adviye İNAN, Duygu ÖZER, Banu Özen BARUT
}

Sağlık Bilimleri Üniversitesi, Kartal Dr. Lütfi Kırdar Eğitim ve Araştırma Hastanesi, Nöroloji Kliniği, İstanbul, Türkiye

\section{Özet}

Amaç: Bu çalıșmanın amacı genç inme hastalarında inme etiyolojisinin ve risk faktörlerinin yaş ve cinsiyet ile ilișkisinin araștırılması ve tekrarlayan inme geçiren hastalarda inme tekrarına neden olabilecek olası risk faktörlerinin saptanmasıdır.

Gereç ve Yöntemler: Hastanemizde akut iskemik inme tanısıyla yatırılmış 55 yaş ve altı 150 hastanın kayıtları retrospektif olarak incelenmiştir. Hastaların demografik özellikleri, vasküler risk faktörleri, inme etiyolojisine yönelik biyokimyasal tetkikleri ve görüntüleme bulguları kaydedilmiștir. İnme alt tipleri TOAST sınıflaması kullanılarak belirlenmiştir. İlk kez ve tekrarlayan inme geçiren hastaların risk faktörleri ve inme alt tipleri cinsiyet ve yaşa göre değerlendirilmiștir.

Bulgular: Hastaların 111’i erkek (\%74), 39’u kadındı (\%26). 83’ü (\%55.3) 45 yaș ve altındaydı. En sık izlenen risk faktörleri hipertansiyon (HT) (\%46), sigara içmek (\%45.3) ve dislipidemi ( \%32.7) idi. Sigara içme oranı erkeklerde anlamlı bir şekilde yüksekti $(\mathrm{p}<0.0001)$. Hipertansiyon ve diabetes mellitus 45 yaș üstü hasta grubunda daha fazlaydı $(p=0.009, p=0.022)$. Erkeklerde yaș grubu ve hipertansiyon arasında istatistiksel olarak anlamlı bir ilișki saptandı $(\mathrm{p}=0.003)$. Küçük damar hastalığı her iki yaş grubunda en sık izlenen inme alt tipiydi. 19 hastada (\%12.6) tekrarlayan inme saptandı. Risk faktörleri ve inme alt tipi açısından ilk kez ve tekrarlayıcı inme geçiren hasta grupları arasında istatistiksel olarak anlamlı bir fark saptanmadı.

Sonuç: Hipertansiyon, sigara içmek ve hiperlipidemi genç popülasyonda sık izlenen inme risk faktörleri olup, 45 yaş üstü hipertansif ve diyabetik erkeklerde inme riski daha fazladır. Genç hastalarda değiştirilebilir risk faktörlerinin saptanıp tedavi edilmesi inme tekrarının önlenmesi açısından önemlidir.

Anahtar Kelimeler: Genç iskemik inme, İnme risk faktörleri, İnme etiyolojisi, Tekrarlayıcı inme

\section{Abstract}

Objective: The aim of this study is to investigate the association of age and gender with stroke etiology and risk factors in young patients with ischemic stroke and to determine probable risk factors causing stroke recurrence in patients with recurrent stroke.

Material and Methods: Records of 150 patients under the age of 55 who were admitted with the diagnosis of acute ischemic stroke in our hospital were reviewed retrospectively. Patients' demograhic data, vascular risk factors, biochemical tests and imaging findings for stroke etiology were recorded. Etiologic stroke subtypes were determined using TOAST classification. Risk factors and stroke subtypes of the patients with first-time stroke and recurrent stroke were evaluatedaccording to gender and age.

Results: 111 (74\%) of the patients were male, $39(26 \%)$ were female. 83 patients (55.3\%) were 45 years of age and younger. The most common risk factors were hypertension ( $46 \%$ ), smoking $(45.3 \%$ ) and dyslipidemia (32.7\%). The rate of smoking among the males were significantly high ( $p<0.0001)$. Hypertension and diabetes mellitus were more common in patients older than 45 years of age $(\mathrm{p}=0.009, \mathrm{p}=0.022)$. A statistically significant relationship with age and hypertension in male patients was determined $(\mathrm{p}=.003)$. Small vessel disease was the most common stroke subtype in both age groups. 19 patients $(12.6 \%)$ had recurrent stroke. No statistically significant difference was detected between the patients' groups of first-time and recurrent stroke regarding to risk factors and stroke subtype.

Conclusion: Hypertension, smoking and hyperlipidemia are the most common risk factors in young population and stroke risk is higher in diabetic and hypertensive males aged 45 and older. To detect and treat the modifiable risk factors in young patients is important to prevent stroke recurrence.

Key words: Young ischemic stroke, Stroke risk factors, Stroke etiology, Recurrent stroke

Yazışma adresi: Rahşan Adviye İNAN, Sağlık Bilimleri Üniversitesi Kartal Dr. Lütfi Kırdar Eğitim ve Araştırma Hastanesi, İstanbul, Türkiye, Telefon: +905323239450, Mail: rahinan@yahoo.com

ORCID No (Sirasiyla):0000-0002-6084-055X,0000-0001-9234-895X,0000-0001-6299-1338

Geliş tarihi: 10.05 .2020

Kabul tarihi: 22.07.2020

DOI: $10.17517 /$ ksutfd. 735340 


\section{GÍRİş}

İnme, genel popülasyonda morbidite ve mortalitenin en önde gelen nedenleri arasında yer almaktadır (1-3). 49 yaş altındaki inmeler genç inme olarak adlandırlır ve tüm inmelerin yaklaşı \% 5-20'sini oluşturmaktadır (3-8). Genç popülasyonda inme insidansı 2.5-40/100.000 arasında değişmekte olup (9-11), insidans 35 yaş üzerinde artmakta ve 18- 44 yaş arası kadınlarda erkeklere göre inme daha fazla görülmektedir (12).

Genç inme hastalarındaki risk faktörleri ve etiyolojik nedenler yaşlı hastalardan farklılık göstermektedir. Yaşlı popülasyonda hipertansiyon (HT), diabetes mellitus (DM) ve kalp hastalıkları en sık rastlanan risk faktörleri (8) iken, gençlerde en sık görülen üç risk faktörü dislipidemi, sigara kullanımı ve hipertansiyon olarak bildirilmiştir (13-15).

Günümüzde görüntüleme yöntemleri, hematolojik ve genetik çalışmalar gibi tanısal araçların daha yaygın ve kapsamlı bir şekilde kullanılıyor olmasına karşın, genç inme hastalarının \%20-30'unda bir etiyoloji saptanamamaktadır (8). Büyük damar aterosklerozu ve küçük damar hastalıkları genç inme hastalarının \%3-\%42.5 kadarında görülebilirken, kardiyoembolik inme \%12.6'dan \%54'e kadar değişen bir oranda etiyolojiden sorumlu tutulmaktadır (16).

$\mathrm{Bu}$ çalışmanın birincil amacı inme merkezimizde yatarak tedavi görmüş 45 yaş altı genç hastalar ile 45-55 yaş arası hastalarda inme etiyolojisinin ve risk faktörlerinin karşılaştırılmasıdır. İkincil olarak bu hasta popülasyonu içinde tekrarlayan inme geçiren grupta bu duruma neden olabilecek belirleyici risk faktörlerinin saptanmasıdır.

\section{GEREÇ ve YÖNTEMLER}

Bu çalışmaya Ocak 2017- Ocak 2019 tarihleri arasında hastanemizde akut iskemik inme tanısıyla yatarak tedavi gören 55 yaş altı 150 hasta dahil edilmiş olup, hastaların kayıtları retrospektif olarak incelenmiştir. Bu çalışma Helsinki Deklerasyonu prensiplerine uygun olarak gerçekleştirilmiştir. Çalışma yerel etik kurul tarafından onaylanmıştır.

Çalışmaya dahil edilen tüm hastaların tıbbi kayıtları aşağıda sırasıyla belirtilen serebrovasküler hastalık risk faktörleri açısından taranmıştır: Yaş, cinsiyet, hipertansiyon, DM, dislipidemi, kardiyak hastalıklar (atrial fibrilasyon, kalp kapak hastalıkları, koroner arter hastalığı), sigara ve alkol kullanımı, migren, oral kontraseptif kullanımı (kadın hastalar için), inme açısından aile öyküsü, hastanın inme ve geçici iskemik atak (GİA) geçirme öyküsü. Ancak retrospektif bir çalışma olduğu için diğer risk faktörlerinden olan hastaların beslenme şekilleri, diyeti, obezite varlığı ve fiziksel aktivite durumu sorgulanamamıştır. HT için kan basıncı >140 / 90 mmHg yüksek olanlar, DM için diyabet öyküsü olanlar, oral antidiyabetik ya da insülin kullanmakta olanlar ya da açlık kan glukozu $126 \mathrm{mg} / \mathrm{dl}$ üzerinde olanlar, hiperkolesterolemi için LDL serum düzeyi $125 \mathrm{mg} / \mathrm{dl}$ üzerinde olanlar değerlendirmeye alınmıştır.İnme tanısı, ani fokal nörolojik defisit ile beraber, enfarktın görüntülemede saptanması ile konmuştur. GİA tanısı ise 24 saat içinde düzelen ani fokal nörolojik defisit sorgulanarak hasta anamnezine dayanılarak konulmuştur.
Tüm hastalarda inme etiyolojisini belirlemeye yönelik olarak rutin biyokimyasal tetkikler, hiperkoagülabilite [protrombin zaman1, aktive parsiyel tromboplastin zamanı, antifosfolipid antikorları, lupus antikoagülanı, homosistein, fibrinojen, protein $\mathrm{C}$, protein $\mathrm{S}$, aktive protein $\mathrm{C}$ direnci, antitrombin III, faktör V Leiden mutasyonu, metilen tetrahidrofolat redüktaz (MTHFR) ve plazminojen aktivatör inhibitör tip 1 (PAI-1) gen mutasyonu] ve vaskülit belirteçlerini (romatoid faktör, anti-nükleer antikor, antinötrofilsitoplazmik antikor, kompleman C3 ve C4, kriyoglobulinler) içeren laboratuvar testleri ile elektrokardiyografi incelenmiştir.

Hastalarda inme tipini belirlemek amacı ile vasküler değerlendirmeler bilgisayarlı beyin tomografileri (BBT), difüzyon ağırlıklı manyetik rezonans görüntülemeleri (MR), karotis vertebral doppler ultrasonografisi, beyin-boyun BT ve MR anjiyografi sonuçları ayrıntılı incelenerek yapıldı. Kardiyak kökenli emboli varlığının araştırılması için transtorasik ve/veya transözofageal ekokardiyografi, 24saatlik ritim holter monitorizasyonu sonuçları değerlendirmeye alınd. Bu değerlendirmeler sonucunda the Trial of Org 10172 in Acute Stroke Treatment (TOAST) kriterleri kullanılarak hastalar 5 etiyolojik kategoriye ayrıldı: (1) Aterosklerotik büyük damar hastalığı, (2) Kardiyoembolik, (3) Küçük damar hastalığı, (4) Diğer nedenler ve (5) Sinıflandırılamayan (sebebi bilinmeyen, kriptojenik).

Hastaların ilk başvuru sırasındaki Ulusal Sağlık Enstitüsü İnme Ölçeği 'National Institute of Health Stroke Scale' (NIHSS) skorları [(0-6) hafif, (7-14) orta, (>15) ağır], tekrarlayıcı inme oranları, hastanedeki mortalite oranları ve hastaneden çıkış modifiye Rankin Skorları (mRS) 0- 6 puan arasında değerlendirilerek kaydedildi.

Tüm veriler kaydedildikten sonra hastalar önce cinsiyetlerine göre, daha sonra 45 yaş altı ve üstü olmak üzere yaş gruplarına ayrılarak vasküler risk faktörlerinin ve inme alt tiplerinin gruplar arasındaki dağılımı değerlendirildi. Ayrıca alt grup analizi olarak tekrarlayan inme geçiren hastalar aynı yöntemle tekrar değerlendirildi.

Istatistik analiz: Hastalara ait verilerin analizi SPSS 19.0 paket programında yapıldı. Çalışmada kategorik değişkenlerin bağımsız gruplar arası karşılaştırmalarında Pearson ki-kare testi, ortalamaların karşılaştırılmasında tek yönlü bağımsız örneklemler $\mathrm{t}$ testi kullanıldı. Tüm analizlerde $\mathrm{p}$ değeri 0,05’in altındaki karşılaştırmalar istatistiksel olarak anlamlı kabul edildi.

\section{BULGULAR}

Çalışmaya alınan 150 hastanın 111'i erkek (\%74),39'u kadındı (\%26). Hastaların yaş ortalaması sırasıyla $43.9 \pm 0.67$ ve $44.05 \pm 1.32$ yıldı. Hastaların 83’ü (\%55.3) 45 yaş ve altında iken, 67 hasta (\%44.7) 45 yaş üstündeydi. Çalışmaya dahil edilen en genç hasta 17 yaşındaydı. Hastaların demografik özellikleri, risk faktörleri ve klinik özellikleri Tablo 1' de gösterilmiştir. Hastaların tümünde en sık izlenen risk faktörü HT (\%46) idi. İkinci ve üçüncü sıklıkla sigara içmek (\%45.3) ve dislipidemi ( \%32.7) saptandi. 


\section{Tablo 1. Grupların demografik ve klinik özellikleri}

\begin{tabular}{|c|c|c|c|c|c|c|c|}
\hline & $\begin{array}{l}\text { Tümü } \\
(\mathrm{n}: 150)\end{array}$ & $\begin{array}{l}\text { Kadın } \\
(\mathrm{n}: 39)\end{array}$ & $\begin{array}{l}\text { Erkek } \\
(\mathrm{n}: 111)\end{array}$ & $P$ değeri & $\begin{array}{l}18-45 \text { yaş } \\
(\mathrm{n}: 83)\end{array}$ & $\begin{array}{l}46-55 \text { yaş } \\
\text { (n:67) }\end{array}$ & $\mathrm{P}$ değeri \\
\hline Yaş (yıl, ort $\pm S S$ ) & $43,99 \pm 0,6$ & $44,05 \pm 1,32$ & $43,9 \pm 0,67$ & $0,002^{*}$ & $37,9 \pm 0,66$ & $49,46 \pm 0,37$ & \\
\hline HT,n,(\%) & $69(46)$ & $17(43,6)$ & $52(46,8)$ & 0,44 & $29(35,2)$ & $37(55,7)$ & $0,009^{*}$ \\
\hline $\mathrm{DM}, \mathrm{n},(\%)$ & $40(26,7)$ & $9(23,1)$ & $31(27,9)$ & 0,36 & $15(18,3)$ & $23(34,2)$ & $0,022^{*}$ \\
\hline $\begin{array}{l}\text { Dislipidemi, } \\
\text { n (\%) }\end{array}$ & $49(32,7)$ & $14(35,9)$ & $35(31,5)$ & 0,38 & $29(35,2)$ & $20(30,4)$ & 0,32 \\
\hline AF,n, (\%) & $5(3,3)$ & $0(0)$ & $5(4,5)$ & 0,22 & $4(5,6)$ & $1(1,3)$ & 0,15 \\
\hline KKH,n, (\%) & $6(4)$ & $1(2,6)$ & $5(4,5)$ & 0,51 & $4(5,6)$ & $2(2,5)$ & 0,29 \\
\hline KAH,n, (\%) & $10(6,7)$ & $2(5,1)$ & $8(7,2)$ & 0,49 & $6(7)$ & $4(6,3)$ & 0,56 \\
\hline $\begin{array}{l}\text { Gíö (n) } \\
(\%)\end{array}$ & $17(11,3)$ & $5(12,8)$ & $12(10,8)$ & 0,47 & $7(8,5)$ & $10(13,9)$ & 0,21 \\
\hline $\begin{array}{l}\text { GİA öyküsü n, } \\
(\%)\end{array}$ & $2(1,3)$ & $1(2,6)$ & $1(0,9)$ & 0,45 & $1(1,4)$ & $1(1,3)$ & 0,94 \\
\hline Aile Öyküsü & $11(7,3)$ & $3(7,7)$ & $8(7,2)$ & 0,58 & $6(7)$ & $5(7,6)$ & 0,57 \\
\hline Sigara & $68(45,3)$ & $8(20,5)$ & $60(54,1)$ & $<0,0001^{\star}$ & $37(45,1)$ & $31(45,6)$ & 0,54 \\
\hline Alkol & $5(3,3)$ & $0(0)$ & $5(4,5)$ & 0,22 & $1(1,4)$ & $4(5,1)$ & 0,22 \\
\hline Migren & $6(4)$ & $3(7,7)$ & $3(2,7)$ & 0,17 & $5(6,02)$ & $1(1,4)$ & 0,08 \\
\hline OK Kul.,n (\%) & - & $6(15,3)$ & - & - & - & - & \\
\hline $\begin{array}{l}\text { Giriş NIHSS, ort } \\
\pm \text { SS }\end{array}$ & $3,59 \pm 0,28$ & $2,82 \pm 0,4$ & $3,86 \pm 0,36$ & 0,22 & $4 \pm 0,47$ & $3,23 \pm 0,33$ & 0,06 \\
\hline $\begin{array}{l}\text { Çıkış MRS, ort } \\
\pm \text { SS }\end{array}$ & $1,39 \pm 0,09$ & $1,28 \pm 0,14$ & $1,43 \pm 0,11$ & 0,06 & $1,46 \pm 0,13$ & $1,33 \pm 0,13$ & 0,61 \\
\hline Mortalite (n), (\%) & $1(0,7)$ & $0(0)$ & $1(0,9)$ & 0,74 & $0(0)$ & $1(1,3)$ & 0,53 \\
\hline \multicolumn{8}{|c|}{$\begin{array}{l}\text { Kisaltmalar } \\
\text { SS:standart sapma, HT:hipertansiyon, DM:diabetes mellitus, AF:atriyal fibrilasyon, KKH:kalp kapak hastalığı, } \\
\text { KAH;koroner arter hastallğ̆ı, GíÖ; geçirilmiş inme öyküsü, GİA;geçici iskemik atak, OK;oral kontraseptif, NIHSS: ulusal } \\
\text { sağllk enstitüsü inme ölçeği 'National Institutes of Health Stroke Scale, MRS:modifiye rankin skalası }\end{array}$} \\
\hline
\end{tabular}

Cinsiyet ve risk faktörleri arasındaki ilişki değerlendirildiğinde sigara içme oranı erkeklerde kadınlara göre istatistiksel olarak anlamlı bir şekilde yüksek bulundu $(\mathrm{p}<0.0001)$. Diğer risk faktörleri ile cinsiyet arasında anlamlı bir ilişki saptanmadi.

Sorgulanan risk faktörleri yaş gruplarına göre değerlendirildiğinde HT ve DM sıklığında anlamlı farkllık görülmüş olup 45 yaş üzerindekilerde HT ve DM daha fazla idi(p= $0.009, \mathrm{p}=0.022) .45-55$ yaş grubundaki hastaların $\% 55.7$ 'si HT, \%34.2'si DM hastası iken, 45 yaş ve altı grupta bu oran $\% 35.2$ ve \%18.3 olarak tespit edildi. Diğer vasküler risk faktörleri açısından her iki grup arasında istatiksel olarak anlamlı bir fark izlenmedi.

Yaş grupları ve cinsiyet birlikte değerlendirildiğinde kadınlarda anlamlı bir fark bulunmazken, erkeklerde yaş grubu ve HT arasın- da istatistiksel olarak anlamlı bir ilişki saptandı $(\mathrm{p}=.003) .45-55$ yaş aralığındaki erkeklerin \%57’si HT hastasıyken bu oranın 45 yaş altı hastalarda $\% 36$ olduğu tespit edildi.

Tüm iskemik inmeli hastaların hastaneye giriş ortalama NIHSS skoru $3.59 \pm 0.28$ olup, \%86'sında çıkış mRS skoru 0-2 arasında, \%14'ünde 3- 5 arasındaydı. Kadın ve erkek cinsiyet ile, $<45$ yaş ve $>45$ yaş gruplar arasında giriş NIHSS skoru ve hastaneden çıkıştaki ortalama mRS skoru oranları arasında anlamlı fark saptanmadı (Tablo 1). Hastane yatı̧ıı sırasındaki mortalite oranı \%0.7 $(\mathrm{n}=1)$ idi. Taburculuktaki mRS skoru 0-2 arasında olan hastaların giriş NIHSS skoru ortalama $3 \pm 3.48$ iken,mRS skoru 3-5 arasında olan hastaların giriş NIHSS skoru $9.5 \pm 3.44$ idi.

96 hastada (\%64) ön sistem, 54 hastada (\%36) arka sistem sulama alanlarına uyan iskemik inme tespit edildi. Yaş 
gruplarına göre inmenin topografik dağılımı açısından anlamlı fark saptanmadı. Hastaların inme etiyolojiler iTOAST sınıflamasına göre 61'inde (\%40.7)küçük damar hastalığı, 29'unda (\%19.3) sebebi bilinmeyen, 28'inde (\%18.7) büyük damar hastalığı, 19'unda (\%12.6) kardiyoembolik ve 13'ünde (\%8.6) diğer nedenler olarak belirlendi (Tablo 2). Kardioembolik inme grubunda saptanan bulgular hipokinetik sol ventrikül (n:6), atrial fibrilasyon (n:5), patent foramen ovale (PFO) (n:4), romatizmal kapak hastalığ + PFO (n:1), dilate kardiyomiyopati (n:1), akinetik sol ventrikül (n:1), ve konjestif kalp yetmezliği (n:1) idi. Diğer nedenlere bağlı inme grubunda saptanan etiyolojiler PAI homozigot mutasyonu (n:4), MTHFR homozigot mutasyonu (n:3), Fabry hastalı̆̆ (n:1), paraneoplastik (n:1), oral kontraseptif kullanımı (n:1), polisitemia vera (n:1), vertebral arter diseksiyonu (n:1), ve hiperhomosisteinemi (n:1)] olarak belirlendi.Küçük damar hastalığı 45 yaş altı ve üstü her iki grupta da en sık etiyolojik alt grubu oluştururken, inme alt tipleri açısından cinsiyet ve yaş grupları arasında anlamlı bir fark saptanmadı.
Hastaların \%11.3 (n:17)' ünde geçirilmiş inme; \%1.3 (n:2)' ünde geçirilmiş GİA öyküsü mevcut olup, tüm hastalarda geçirilmiş atak sayısı 1'idi. İlk inme atağını ortalama $2.88 \pm 2.54$ yıl önce geçiren 19 hastanın 13'ü erkek (\%68.4) 6’sı kadındı (\%31.6). Sekizi (\%42.1) 45 yaş ve altı, 11'i (\%57.9) 45 yaş üzerinde olup, tekrarlayıcı inme oranı açısından cinsiyet ve yaş grupları arasında istatistiksel olarak anlamlı fark saptanmadi. Bu grupta en sık izlenen risk faktörleri sırasıyla hipertansiyon (\%57.9), sigara içme (\%36.8), DM (\%31.6) ve dislipidemi (\%26.3) olarak tespit edildi. Hastaların inme etiyolojileri TOAST sınıflamasına göre 11'inde (\%57.9) küçük damar hastalığı, 3’ünde(\%15.8) sebebi bilinmeyen, 2'sinde (\%10.5) diğer nedenler,2'sinde (\%10.5) büyük damar hastalığı, 1’inde (\%5.3) kardiyoembolik olarak belirlendi. Vasküler risk faktörleri ve etiyolojik inme alt tipi açısından ilk kez ve tekrarlayıcı inme geçiren hasta grupları arasında istatistiksel olarak anlamlı bir fark saptanmadı. Hastaların 11'inin (\%57.89) geçirdikleri ilk atak sonrası başlanan antiagregan tedaviyi yarım bıraktığı ya da düzensiz kullandıkları öğrenildi.

\section{Tablo 2. Gruplardaki Etiyolojik İnme Alt tipleri}

\begin{tabular}{|l|l|l|l|l|l|l|l|} 
& $\begin{array}{l}\text { Tümü } \\
\text { (n:150) }\end{array}$ & $\begin{array}{l}\text { Kadın } \\
\text { (n:39) }\end{array}$ & $\begin{array}{l}\text { Erkek } \\
\text { (n:111) }\end{array}$ & P değeri & $\begin{array}{l}\mathbf{1 8 - 4 5} \text { yaş } \\
(\mathbf{n : 8 3 )}\end{array}$ & $\begin{array}{l}\text { 46-55 yaş } \\
\text { (n:67) }\end{array}$ & P değeri \\
\hline $\begin{array}{l}\text { Aterosklerotik } \\
\text { büyük damar } \\
\text { hastalığı, n, (\%) }\end{array}$ & $28(18,7)$ & $5(12,8)$ & $23(20,7)$ & 0,2 & $14(16,9)$ & $14(20,3)$ & 0,38 \\
\hline $\begin{array}{l}\text { Kardiyoembolik } \\
\text { n, (\%) }\end{array}$ & $19(12,6)$ & $5(12,8)$ & $14(12,6)$ & 0,58 & $14(16,9)$ & $5(8,9)$ & 0,11 \\
\hline $\begin{array}{l}\text { Küçük damar } \\
\text { hastalığı, n, (\%) }\end{array}$ & $61(40,7)$ & $18(46,2)$ & $43(38,7)$ & 0,42 & $31(38)$ & $30(43)$ & 0,32 \\
\hline $\begin{array}{l}\text { Diğer nedenler, n, } \\
\text { (\%) }\end{array}$ & $13(8,6)$ & $5(12,8)$ & $8(7,2)$ & 0,34 & $8(9,6)$ & $5(7,4)$ & 0,45 \\
\hline $\begin{array}{l}\text { Sebebi bilinmeyen, } \\
\text { n, (\%) }\end{array}$ & $29(19,3)$ & $6(15,3)$ & $23(20,7)$ & 0,32 & $16(19,2)$ & $13(19,4)$ & 0,48 \\
\hline
\end{tabular}

\section{TARTIŞMA}

İnme etiyolojisinde tanısal değerlendirmelerde giderek artan gelişmeler sayesinde iskeminin spesifik nedenleri ortaya konabilen hasta grubu oranı artmaktadır. Bugün için hastaların \% 80'ninde somut bir neden ortaya konulabilmektedir (6).

Değiştirilebilir risk faktörleri genç ve yaşlı hasta grupları için aynı olmakla birlikte bu risk faktörlerinin prevalansı her iki grupta aynı değildir. HT, kalp hastalıkları ve DM yaşlı popülasyonda en sık görülen risk faktörleridir (18). Ancak genç inmeli hastalarda yapılan çalışmalar arttıkça genel olarak kabul edilen bu durumun tersine sonuçlar bildirilmeye başlanmıştır. Putaala ve ark. tarafından Finlandiya'da 1008 genç inme hastasında yapılan bir çalışmada en sık izlenen vasküler risk faktörleri dislipidemi (\%60), sigara içmek (\%44) ve HT
(\%39) olarak bildirilmiştir (10). Aynı yazar tarafından Avrupa’nın üç farklı coğrafik bölgesinde 3944 genç inme hastasında yapılan çalışmada vasküler risk faktörlerinin dağılımı sigara içmek (\%49), dislipidemi (\%46) ve HT (\%36) olarak saptanmıştır (14). Literatürde genç hastalarda risk faktör profiline yönelik yapılan çalışma sonuçlarıylauyumlu olarak bizim çalışmamızda da erkek cinsiyet genc iskemik inmelerde dahasık bulunmuş ve tüm hasta grubu içinde en sık rastlanan üç risk faktörü hipertansiyon (\%46), sigara kullanımı (\%45.3) ve dislipidemi (\%32.7) olarak saptanmıştır (10,1315,19-23). Takip eden risk faktörleri DM (\%26.7), kardiyak nedenler (\%14) ve geçirilmiş inme ya da GİA öyküsü (\%12.6) idi. Gençlerde inme etiyolojisi çeşitlilik gösterir; yaş ve cinsiyete göre değişebilir (19). İnme risk faktörlerinin dağıllmında yaş ve cinsiyetin etkisini değerlendirdiğimizde sigara içmek erkek hastalar arasında anlamlı şekilde daha fazlaydı; 
46- 55 yaş grubunda ise HT ve DM öne çıkan risk faktörleriydi.45 yaş üstüve altı yaş gruplarının karşılaştırıldığı bir çalışmada ise HT, DM, AF ve koroner arter hastalığı sıklığı 45 yaş üstü grupta daha fazlaydı (24). Ailede inme öyküsünün varlığı 29-39 yaş arası genç inme hastalarında 40-49 yaş grubuna göre belirgin bir risk faktörü olduğu ve özellikle diğer nedenlere bağlı etiyolojik alt grupta aile öyküsü olma oranının daha yüksek olduğunu bildiren çalışmalar mevcut olsa da çalışmamızda aile öyküsü ve etiyolojik inme tipleri yaş gruplarına göre değerlendirildiğinde anlamlı bir fark saptanmamıştır (25).

Literatürde, genç hastalarda, iskemik inme alt gruplarının belirlenmesinde TOAST kriterlerinin kullanıldığı çalışmalarda farklı sonuçlar elde edilmiştir. Kardiyoembolik, aterosklerotik, sebebi bilinmeyen inmeler ile diğer nedenlere bağlı inmeninen sık neden olarak gösterildiği çalışmaların aksine bu çalışmada hem 45 yaş altı hem de 45 yaş üstü iskemik inme hastalarımızda en sık görülen etiyolojik neden küçük damar hastalığıdır (\%40.7) (5-7,13,18,20,22,23,26-29). Bunu sırasıyla sebebi bilinmeyen, büyük damar aterosklero$\mathrm{zu}$, kardiyoembolik ve diğer etiyolojilere bağlı nedenler takip etmektedir. Çalışmamızda inme alt grubunun cinsiyet ve yaş gruplarına göre dağılımında gruplar arasında anlamlı bir fark izlenmedi. 18- 55 yaş arası 4467 hastadan oluşan çok uluslu geniş Avrupakohortunda (sifap1 çalışması) küçük damar hastalığı oranını \%29.2 olarak bildirilmiştir (30). Tancredi ve ark.'nın324 hastayı retrospektif olarak değerlendirdikleri çalışmada küçük damar hastalığı; diğer nedenler, sebebi bilinmeyen ve kardiyoembolik nedenlerden sonra dördüncü sırada olup hastaların \%15.7'sinde etiyolojik neden olarak saptanmıştır. Vasküler risk faktörlerinin inme alt tipleriyle ilişkisinin değerlendirildiği alt grup analizlerinde ise HT, dislipidemi ve sigara içme oranlarının küçük damar hastalığı grubunda en yüksek olduğunu bildirmişlerdir (28). Bizim çalışmamızda da küçük damar hastalığının en sık olmasının sebebi sigara içme oranının yüksek olması olabilir. Arboix A. ve ark.sigara içmenin ( > 20 adet/gün) genç yaşta görülen laküner enfarktlar için bağımsız bir risk faktörü olduğunu belirtmişlerdir (31).

Bizim çalışmamızda küçük damar hastalığından sonra ikinci en slklıkta (\%19.3) saptanan inme alt tipi sebebi belirlenemeyen grup idi. Hastaların \% 20-30'unda kapsamlı bir etiyolojik araştırmaya rağmen inme nedeni tespit edilemeyebilir. Bu hastalarda klasik vasküler risk faktörleri olsa bile, aterosklerotik ya da küçük damar hastalığına işaret eden bulgulara rastlanmaz $(8,16)$. Bununla birlikte sebebi bilinmeyen (kriptojenik) inmelerin \% 43'ünün kardiyojenik nedenlere bağlı olduğu öne sürülmüştür (32). Bazı çalışmalarda kriptojenik inmenin 45- 54 yaş arasında daha sık görüldüğü bildirilmesine karşın, bizim çalışmamızda her iki yaş grubu arasında anlamlı fark saptamadık (21). Yazarların önerdiği gibi sonuçlar değişkenlik gösterebileceğinden biyokimyasal test sonuçlarının tekrarlanmasına ve hastaların çoğunda Holter ve TEE çekilmesine rağmen bu hastalarda bir etiyoloji sap- tayamadık. Ancak bu hastalarda özellikle reverzibl serebral vazokonstrüksiyon, inrakranyal ateroskleroz, vaskülit ya da diğer vaskülopatilerin dışlanabilmesi için serebral anjiyografi yapılması ve gereğinde tekrarlanması önerilmektedir (16). Kriptojenik inme oranının yüksek bulunmasının nedeni etiyolojik sınıflandırma için TOAST kriterlerinin kullanılması da olabilir. CSS ( causative classification of stroke system) ve ASCO (atherosclerosis, small vessel disease, cardiac source, other cause) sınıflamalarının kullanılmasının genç inmeli hastalarda TOAST siniflamasına göre nedeni belirlenemeyen hasta oranını düşürdügü bildirilmiştir (33).

Bazı çalışmalarda 45 yaş altı hastalarda arka sistem enfarktlarının yaşlı gruba göre daha yüksek oranda (\%25-46) görüldüğü bildirilmiş,bazı çalışmalarda ise 19-45 yaş arası inme grubunda ön sistem enfarktları daha yüksek oranda bulunmuştur $(23,34)$. Bizim çalışmamızda yaş grupları ile inmenin topografik dağılımı arasında istatiksel olarak anlamlı fark bulunmadi.

Tekrarlayıcı inme sıklığı gençlerde yaşlı popülasyona göre daha az sıklıkta görülmekte olup,18- 45 yaş arası ilk inmesini geçiren hastalarda 10. yılda kümülatif risk \%14.7 olarak saptanmıştır $(35,36)$. Literatatürde birçok çalışmada vasküler olayın tekrarı ile ilişkili olabilecek risk faktörleri aterotrombotik inme tipi, 35 yaş üzerinde olmak, ailede inme öyküsü olması, auralı migren varlığı, ikincil koruma nedeniyle kullanilmakta olan antiagregan ve antihipertansif tedavilerin kesilmesi, antifosfolipid antikor varlığ 1 ve klasik vasküler risk faktörlerinin varlığı (hipertansiyon, DM, sigara içme, hiperkolesterolemi) olarak bildirilmiştir $(5,6,35,36)$. Bizim hasta grubumuzda tekrarlayan inme geçiren hasta oranı $\% 12.6 \mathrm{bu}-$ lunmuş olup, literatürden farklı olarak en sık izlenen etiyoloji küçük damar hastalığı idi. Ayrıca, demografik özellikler, vasküler risk faktörleri ve inme etiyolojisi açısından ilk kez inme geçiren hasta grubuna göre farklılık saptanmadı. Ancak hastaların \%57.89 'unun ikincil koruma amaçlı başlanan antiagregan tedavilerini düzensiz kullanmaları ya da hiç kullanmamış olmaları inmenin tekrarlamasında önemli bir risk faktörü olduğu şeklinde yorumlandı.

Genç hastalarda inme prognozu yaşlı popülasyona göre genellikle daha iyidir. 18- 50 yaş arası inme geçiren hastaların ortalama 11 yıl boyunca takip edildiği bir çalışmada mortalite oranı \%20 olarak bildirilmiştir (37). Genç inme geçiren hastalarda uzun süreli takiplerin yapıldı̆̆ talite nedenlerinin kardiyoembolik inme tipi, erkek cinsiyet, ileri yaş ve hastaneye yatış sırasındaki yüksek NIHSS olarak saptanmıştır $(5,13,35,37)$. Hastane mortalite oranları ise $\% 0$ 4.1 bildirilmiş olup, bu çalışmada \%0.7 olarak saptanmıştır $(5,20)$. Çalışmaya alınan hastaların hastane giriş ortalama NIHSS skoru hafif düzeyde $(3.59 \pm 0.2$ olup, çıkış mRS skoru $1.39 \pm 0.09$ bulundu. NIHSS skorlarının düşük olması bu hastaların çıkış mRS skorlarının da düşük olmasına neden olmuştur. Hastaların \%14'ünde taburculuktaki mRS skoru $>3$ olup, mRS skorlarında cinsiyet ve yaş gruplarına göre yapılan değerlendirmelerde bir fark saptanmamıştır. 
Çalışmamızın kısıtlılıkları retrospektif ve tek merkezli çalışma olması, hasta sayısının nispeten az olması, hastaların uzun süreli takiplerinin yapılamamıs olması ve sayıca az olmasına karşın bazı hastalarda etiyolojik nedene yönelik araştırmalarda özellikle TEE ve Holter tetkiklerinin eksik kalmasıdır.

Sonuç olarak, çalışmamızda gösterildiği gibi HT, sigara içmek ve hiperlipidemi yaşlı popülasyonda olduğu gibi genç popülasyonda da inmeye yol açan en önemli risk faktörleri olup, 45 yaş üstü hipertansif ve diyabetik erkeklerde bu durum daha belirgin hale gelmektedir. Genç hastalarda inme genellikle daha iyi seyretmekle birlikte değiştirilebilir risk faktörlerinin saptanıp tedavi edilmesi inme tekrarının önlenmesi açısından önemlidir.

Çıkar Çatışması ve Finans Durumu: Çalışmamız bir kurum ve kuruluşça finanse edilme-miştir. Bu çalışmada yazarlar arasında herhangi bir konuda çıkar çatışması bulunmamaktadır.

Araştırmacıların Katkı Oranı Beyan Özeti: Yazarlar makaleye eşit katkı sağlamış olduklarını beyan ederler.

\section{KAYNAKLAR}

1. Feigin VL, Lawes CM, Bennett DA, Barker-Collo SL, Parag V. Worldwide stroke incidence and early case fatality reported in 56 population-based studies: a systematic review.Lancet Neurol. 2009;8(4):355-69.

2. GBD 2016 Neurology Collaborators. Global, regional, and national burden of neurological disorders, 1990-2016: a systematic analysis for the Global Burden of Disease Study 2016.Lancet Neurol. 2019;18(5):459-480.

3. Ekker MS, Verhoeven JI, Vaartjes I, Jolink WMT, Klijn CJM, de Leeuw FE. Association of Stroke Among Adults Aged 18 to 49 Years With Long-term Mortality. JAMA. 2019;321(21):2113 2123.

4. Leys D, Debette S. Epidemiology of ischemic stroke in young adults. In: Pezzini A, Padovani A, eds. Cerebral Ischemia in Young Adults: Pathogenic and Clinical Perspectives, New York: Noca Science Publishers; 2009.p.1-24.

5. Nedeltchev K, der Maur TA, Georgiadis D, Arnold M, Caso V, Mattle HP et. al. Ischaemic stroke in young adults: predictors of outcome and recurrence. J Neurol Neurosurg Psychiatry. 2005;76(2):191-5.

6. Varona JF, Guerra JM, Bermejo F, Molina JA, Gomez de la Camara. Causes of ischemic stroke in young adults, and evolution of the etiological diagnosis over the long term. Eur Neurol. 2007;57:212-218.

7. Bogousslavsky J, Pierre P. Ischemic stroke in patients under age 45. Neurol Clin 1992;10:113-124.

8. Smajlović D. Strokes in young adults: epidemiology and prevention. Vasc Health Risk Manag. 2015;11:157-64.

9. Nawaz B, Eide GE, Fromm A, Øygarden H, Sand KM, Thomassen L et. al. Young ischaemic stroke incidence and demographic characteristics- The Norwegian stroke in the young study- Athree- generation research program. Eur Stroke J. 2019;4(4):347354.

10. Putaala J, Metso AJ, Metso TM, Konkola N, Kraemer Y, Haapaniemi E et. al. Analysis of 1008 consecutive patients aged 15 to 49 with first-ever ischemic stroke: the Helsinki Young Stroke Registry. Stroke. 2009;40:1195-1203.
11. Marini C, Russo T, Felzani G. Incidence of stroke in young adults: a review. Stroke Res Treat. 2011;2011:535672.

12. Ekker MS, Verhoeven JI, Vaartjes I, van Nieuwenhuizen KM, Klijn CJM, de Leeuw FE. Stroke incidence in young adults according to age, subtype, sex, and time trends. Neurology. 2019;21;92(21):e2444-e2454.

13. PutaalaJ, Curtze S, Hiltunen S, Tolppanen H, Kaste M, Tatlisumak T. Causes of death and predictors of 5-year mortality in young adults after first-ever ischémie stroke: the Helsinki Young Stroke Registry. Stroke. 2009;40(8):2698-2703.

14. Putaala J, Yesilot N, Waje-Andreassen U, Pitkaniemi J, Vassilopoulou S, Nardi K et al. Demographic and geographic vascular risk factor differences in European young adults with ischemic stroke: the 15 Cities Young Stroke Study. Stroke. 2012;43: 26242630.

15. Zhang YN, He L. Risk factors study of ischemic stroke in young adults in Southwest China. Sichuan Da Xue Xue Bao Yi Xue Ban. 2012;43: 553-557.

16. Kes VB, Zavareo I, Demarin V. Etiology and diagnostic workup in young stroke patients. Period Biol. 2012;114(3):355-359.

17. Adams HP Jr, Bendixen BH, Kappelle LJ, Biller J, Love BB, Gordon DL et.al. Classification of subtype of acute ischemic stroke. Definitions for use in a multicenter clinical trial. TOAST. Trial of Org 10172 in Acute Stroke Treatment. Stroke. 1993(1):35-41.

18. Smajlović DŽ, Salihović D, Ibrahimagić OĆ, Sinanović O. Characteristics of stroke in young adults in Tuzla Canton, Bosnia and Herzegovina. Coll Antropol. 2013;37:515-519.

19. Lasek-Bal A, Kopyta I, Warsz-Wianecka A, Puz P, Łabuz-Roszak B, Zaręba K. Risk factor profile in patients with stroke at a young age. Neurol Res. 2018;40(7):593-599.

20. Ji R, Schwamm LH, Pervez MA, Singhal AB. Ischemic stroke and transient ischemic attack in young adults: risk factors, diagnostic yield, neuroimaging, and thrombolysis. JAMA Neurol. 2013;70:51-57.

21. Larrue V, Berhoune N, Massabuau P, Calviere L, Raposo N, Viguier A et. al.Etiologic investigation of ischemic stroke in young adults.Neurology. 2011;76:1983-1988.

22. Acar A, Uzar E, Çevik MU, Yücel Y, Cansever S, Arıkanoğlu A et.al. İskemik inmeli genç hastaların demografik, etyolojik ve risk faktörleri. Düzce Tip Dergisi 2012; 14(3): 32-36 32.

23. Chatzikonstantinou A, Wolf ME, Hennerici MG.Ischemic stroke in young adults: classification and risk factors.J Neurol. 2012;259(4):653-9.

24. Özer İŞ, Sorgun MH, Rzayev S, Kuzu M, Tezcan S, Yllmaz V et. al. Genç İskemik İnme Hastalarında İnme Etiyolojisi, Risk Faktörleri ve Hastaların İzlemdeki Fonksiyonel Durumları. Turk J Neurol 2015;21:159-64.

25. Kivioja R, Pietilä A, Martinez-Majander N, Gordin D, Havulinna AS, Salomaa V et al. Risk Factors for Early-Onset Ischemic Stroke: A Case-Control Study.J Am Heart Assoc. 2018;6;7(21):e009774.

26. Kwon SU, Kim JS, Lee JH, Lee MC. Ischemic stroke in Korean young adults. Acta Neurol Scand. 2000;101:19-24.

27. Kittner SJ, Stern BJ, Wozniak M, Buchholz DW, Early CJ, Feeser BR et al. Cerebral infarction in young adults: the Baltimore-Washington Cooperative Young Stroke Study. Neurology 1998; 50: 890-894.

28. Tancredi L, Martinelli Boneschi F, Braga M, Santilli I, Scaccabarozzi C, Lattuada P et al. Stroke care in young patients.Stroke Res Treat. 2013;2013:715380.

29. Fan H, Hao X, Yang S, Li Y, Qin W, Yang L, Yuan J, Hu W.Study on the incidence and risk factor of silent cerebrovascular disea- 
se in young adults with first-ever stroke. Medicine(Baltimore). 2018;97(48):e13311.

30. Wolf ME, Grittner U, Bottcher T, Norrving B, Rolfs A, Hennerici MG et al. Phenotypic ASCO characterisation of young patients with ischemic stroke in the prospective multicentre observational sifap1 study. Cerebrovasc Dis 2015;40:129-35.

31. Arboix A, Jiménez C, Massons J, Parra O, Besses C. Hematological disorders: a commonly unrecognized cause of acute stroke. Expert Rev Hematol. 2016;9:891-901.

32. Moubarak G, Tamazyan R, Garcon P, Join Lambert C, Bruan$\operatorname{det} \mathrm{M}$, Cazeau $\mathrm{S}$ et al. Detection of occult atrial fibrillation by pacemaker interrogation in cryptogenic stroke. J Interv Card Electrophysiol. 2014;39:261-265.

33. Crespo Pimentel B, Willeit J, Töll T, Kiechl S, Pinho E Melo T, Canhão P et al.Etiologic Evaluation of Ischemic Stroke in Young
Adults: A Comparative Study between Two European Centers.J Stroke Cerebrovasc Dis. 2019;28(5):1261-1266.

34. Piechowski-J'o zwiak B, Bogousslavski J. Posterior circulationstrokes. In: Fisher M, ed. Handbook of Clinical Neurology. Stroke Part II: Clinical Manifestations and Pathogenesis. 1st ed. Elsevier; 2008.p.537-558.

35. Varona JF, Bermejo F, Guerra JM, Molina JA. Longterm prognosis of ischémie stroke in young adults: study of 272 cases. J Neurol. 2004;25-1(12):1507-1514.

36. Pezzini A, Grassi M, Lodigiani C, Patella R, Gandolfo C, Zini A et al. Predictors of long-term recurrent vascular events after ischemic stroke at young age: the Italian Project on Stroke in Young Adults.Circulation. 2014;22;129(16):1668-76.

37. Rutten- Jacobs LC, Arntz RM, Maaijwee NA, Schoonderwaldt HC, Dorresteijn LD, van Dijk EJ et al. Long - term mortality after stroke among adults aged 18 to 50 years. JAMA. 2013;20;309(11):1136-44. 